\title{
Articles
}

\section{We Have Not Seen the Last of the Rogue State}

\author{
By Isobel Roele*
}

\section{A. Introduction}

Viewed at a certain angle, the rogue state seems to be in almost necessary relation with the idea of rupture. As Derrida put it in his 2002 lectures on Rogues, the rogue state, état voyou in 'franglaise," "is someone who rattles, who shakes things up, who agitates." ${ }^{2}$ Past and present rogue states like Iran, Iraq, Libya or North Korea, are associated with the acquisition of Weapons of Mass Destruction (WMD), state sponsorship of terrorism and the violation of human rights. These entities pose both external threats to other states and internal threats to their own people. Today, the phrase 'rogue state' may seem to be past its sell-by-date. While the term was not coined by the G.W. Bush administration, during the eight years it was in power in the United States (US), the phrase became strongly associated with the Bush Doctrine, appearing in key security documents as well as speeches. ${ }^{3}$ Under the banner of 'change' President Obama, a Nobel Peace Laureate, has distanced himself from the policies of his predecessor. The phrase 'rogue state' has been expunged from the current National Security Strategy, for instance. ${ }^{4}$

This paper will suggest that the Obama administration might find it difficult to get rid of the concept of the rogue state. The rogue state is too useful a category, and too integral to the Administration's tactic of 'isolation,' to be easily sidelined. The isolation of rogue states has echoes of the exclusion of criminals in national legal systems; as Zygmunt Bauman has explained, societies exclude those who deviate from the norms that constitute the system of order on the grounds that they are "unfit to be free agents." 5 Such unfitness can be used to legitimate different treatment and unequal status. At the international level, the rogue state can be seen as a sort of 'unequal sovereign' ${ }^{6}-$ the criminal state. The criminal is one

* LLB (King's College, London, 2003); LLM (University of Nottingham, 2005); PhD (University of Nottingham, 2009). Lecturer in Law, Cardiff University Email: RoelelH@cf.ac.uk.

${ }^{1}$ JaCques DeRRIDA, Rogues: Two Essays on ReAson (Pascale-Anne Brault and Michael Naas tr., 2003).

${ }^{2}$ Id. at 66 .

${ }^{3}$ National Security Council of USA, National Security Strategy (September 2002).

${ }^{4}$ National Security Council of USA, National Security Strategy (May 2010).

${ }^{5}$ Zygmunt Bauman, Social Issues of Law and Order, 40 BRITISH JouRnAL OF CRIMINOLOGY 205, 207 (2000).

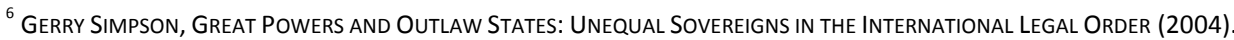


who violates norms of order. The rogue state fits into this mould; as Derrida wrote, voyoucracy stands for disorder.

The rogue state, as a criminal state, is defined by its violations of international obligations. International law norms and institutions play a further role in dealing with such states by restoring order, either by excluding them from the international community or by enforcing their compliance with international obligations. As an idea incompatible with the doctrine of sovereign equality, the concept of the criminal state is controversial and incompatible with the United Nations (UN) Charter commitment to respect the sovereign equality of its members. ${ }^{8}$ It is unlikely to be generally accepted by states unless criminality is equated with an extreme form of deviance. The rogue state, an already established category of deviance, is a relatively uncontroversial target for criminalization.

\section{B. What is a Rogue State?}

There have been various attempts to define the term rogue state. Gerry Simpson has distinguished two sorts of outlaw states; criminal ones and illiberal ones. ${ }^{9}$ It could be said that for criminal states, the focus is on their external relations with other states, while for illiberal ones, more emphasis is put on the internal relationship between regime and people. Rogue states, as a sort of outlaw state, encompass both elements. Some definitions focus on the sorts of material threats to international peace and security that emanate from rogue states; 'criminal' outlaws. For instance, it is said that rogue states are those that sponsor international terrorism or proliferate WMD. ${ }^{10}$ The problem with such a definition is that it does not account for why states such as India or Israel - both of which are widely believed to have violated the norm against proliferation of nuclear weapons are absent from roll calls of rogue states. In response to the inadequacy of mere capability to explain rogue status, an additional element of (nefarious) intention has sometimes been grafted on. ${ }^{11}$

Other definitions are more concerned with the internal manifestations of rogue statehood; 'illiberal' outlaws. For instance, they define rogue states as those that abuse human rights

\footnotetext{
${ }^{7}$ DERRIDA, supra note 2, at 66 .

${ }^{8}$ United Nations Charter art. 2(1): “The Organization is based on the principle of the sovereign equality of all its Members."

${ }^{9}$ SIMPSON, supra note 7 , at 280-281.

${ }^{10}$ See for example, Elizabeth N. Saunders, Setting Boundaries: Can International Society Exclude 'Rogue States'?, 8 INT. STU. REV. 23 (2006).

${ }^{11}$ Robert S. Litwak, The New Calculus of Pre-emption, 44(4) SURVIVAL 53, 67 (2002-3).
} 
and fail to respect democracy. ${ }^{12}$ John Yoo wrote that the US definition of rogue state had two prongs: "[H]uman rights abuses and dangerous ideological regimes." ${ }^{13}$ The problem with the emphasis on such internal policies is that there are several states popularly associated with human rights abuses that are not usually included in the category of rogue state: Burma is one example. ${ }^{14}$ The National Security Strategy of the G.W. Bush Administration combined these external and internal elements. That document listed five features of the rogue state, which are as follows:

Rogue states

- brutalize their own people and squander their national resources for the personal gain of the rulers;

- display no regard for international law, threaten their neighbors, and callously violate international treaties to which they are party;

- $\quad$ are determined to acquire weapons of mass destruction, along with other advanced military technology, to be used as threats or offensively to achieve the aggressive designs of these regimes;

- $\quad$ sponsor terrorism around the globe; and

- reject basic human values and hate the United States and everything for which it stands. ${ }^{15}$

This comprehensive litany of the failings of rogue states underlines the threat posed by them to international order, understood broadly in terms of peace and security, international law and liberal values. Whether criminal, illiberal or both, rogue states are identified by their Otherness: not only do they not share the values or identity of 'normal' states, but they violently oppose them. Madeline Albright said rogue states are the kind that "not only do not have a part in the international system, but whose [sic] very being involves being outside of it [sic] and throwing, literally, hand grenades inside in order to destroy it." ${ }^{16}$ The rogue state is a sort of public enemy: it does not offer an alternative sort of order, but only disorder. ${ }^{17}$ Unlike the US and its allies who are "on the right side of history,"18 the rogue state is "on the wrong side of history." ${ }^{19}$

\footnotetext{
${ }^{12}$ Mary Caprioli \& Peter F. Trumbore, Identifying 'Rogue' States and Testing their Interstate Conflict Behaviour, 9(3) EJIR 377, 378 (2003).

${ }^{13}$ John Yoo, Using Force, 71(3) UNIV. CHI. L.R. 729, 783 (2004).

${ }^{14}$ Robert S. Litwak, Rogue States and US Foreign Policy: Containment After the Cold War (2000).

${ }^{15}$ US NSS 2002, supra note 4, at 14.

16 Madeleine Albright, Speech at Tennessee State University, (Feb. 19 1998), available at: http://secretary.state.gov/www/statements/1998/980219b.html (last accessed: 24 April 2012).

${ }^{17}$ DeRRIDA, supra note 2 , at 66 .

${ }^{18}$ Condoleezza Rice, Promoting the National Interest, 79(1) FoREIGN AfFAIRS 45, 46 (2000).
} 
The Otherness connected with the term rogue state means that it operates as a label rather than as an analytical category. ${ }^{20}$ As a label, it is supposed to help mobilize domestic and international support for action against states so labeled. ${ }^{21}$ Indeed, although it has been more than once suggested that the rogue state label was anathema to the US's potential allies in Europe, ${ }^{22}$ the experience of last decade suggests that the concept - if not the label - has had a mobilizing effect. The label 'rogue state' also has an important negative effect: By casting a state as Other, states which view themselves as members of the international community do not identify with it and are therefore less likely to object to the undermining of the rogue state's sovereignty. For instance, it can enable action against sovereign states that would otherwise be seen as an unjustified intervention in their domestic sphere. ${ }^{23}$

This connects with another sort of understanding of the rogue state that pertains to international law as the law of the international community. Derrida described the rogue state in this way: it is "a state that respects neither its obligations as a state before the law of the world community nor the requirements of international law, a state that flouts the law and scoffs at the constitutional state or state of law." ${ }^{24}$ This sort of definition emphasizes the idea that the rogue state exists outside the community, to the extent that obedience of the law is a characteristic of members of a given community, but inside the law to the extent that obedience is nevertheless demanded of the rogue state. ${ }^{25}$ In this way, the rogue state is "at once included and excluded." ${ }^{26}$ The role played by law in defining and dealing with rogue states introduces the idea of criminality into the picture.

The idea of the rogue state as a criminal entity to be identified through the law and dealt with using legal mechanisms had little currency for the duration of the previous Bush regime. During last decade, the rogue state was treated as a purely external threat to be neutralized. This was commensurate with that administration's preference for unilateral over multilateral action. The criminalization of the rogue state, it is argued, goes hand in

\footnotetext{
${ }^{19}$ Anthony Lake, Confronting Backlash States, 73(2) ForeIGN AfFAIRS 45, 55 (1994).

${ }^{20}$ Robert S. Litwak, Rogue States: A Handy Label but a Lousy Policy, THE WASHINGTON POST, (Feb. 20, 2000).

${ }^{21}$ LITWAK, supra note 15 , at 75 .

${ }^{22}$ Saunders, supra note 11 , at 28; LITWAK, supra note 15, at 11.

${ }^{23}$ UN Charter art. 2(7): “Nothing contained in the present Charter shall authorize the United Nations to intervene in matters which are essentially within the domestic jurisdiction of any state ...."

${ }^{24}$ DERRIDA, supra note 2 , at xiii.

${ }^{25}$ Id. at $10-14$.

${ }^{26}$ Id. at 21.
} 
hand with a multilateral approach to threats, whereby international law and institutions, rather than national ones play the key role, and where community, rather than individualism, underlies the policies. The present Obama administration has taken such an approach.

The movement towards community away from individualism suggests a parallel movement away from sovereign equality and towards criminality. Criminals threaten a community from within; criminal law is public law. Once the move is made to view rogue states as criminals defined by their internal relationship to the community, it can be seen that far from being a disruptive element, the rogue state can have quite the opposite effect; as the Other, it provides a negative point of reference that builds both community identity and agreement.

\section{Pursuing Collective Security through the Rogue State}

While not all measures used to counter the threat posed by rogue states have been multilateral, following Derrida, our focus will be on the UN Security Council (SC). ${ }^{27}$ The SC is responsible for maintaining and restoring international peace and security. ${ }^{28}$ It is capable of imposing binding obligations on UN member states under Chapter VII of the Charter. ${ }^{29}$ In recent years, it has extended the sorts of obligations imposed on member states from specific situations to general threats to international peace and security. ${ }^{30}$ As part of this change of tack, it has formulated counter-proliferation and counter-terrorism regimes, and its activity has often been to hold non-compliant states to account and to ensure their future compliance. Its dealings with Iraq and with Iran and the pursuit and possession of WMD demonstrate this strategy.

The SC is comprised of 15 states: Five permanent members and 10 non-permanent members elected by the General Assembly. Only the permanent members (China, France, Russia, the United Kingdom and the US) have veto rights. ${ }^{31}$ Nearly a decade ago, Derrida

\footnotetext{
${ }^{27}$ Id. at 97.

${ }^{28}$ UN Charter art. 24(1): "In order to ensure prompt and effective action by the United Nations, its Members confer on the Security Council primary responsibility for the maintenance of international peace and security, and agree that in carrying out its duties under this responsibility the Security Council acts on their behalf."

${ }^{29}$ UN Charter art. 25: "The Members of the United Nations agree to accept and carry out the decisions of the Security Council in accordance with the present Charter."

${ }^{30}$ Matthew Happold, Security Council Resolution 1373 and the Constitution of the United Nations, 16 LEIDEN JOURNAL OF INTERNATIONAL LAW (LIL) 593 (2003).

${ }^{31}$ Article 27(3) UN: "Decisions of the Security Council on all other matters shall be made by an affirmative vote of nine members including the concurring votes of the permanent members; provided that, in decisions under Chapter VI, and under paragraph 3 of Article 52, a party to a dispute shall abstain from voting."
} 
complained that the wielding of power by the SC was "a monstrosity." 32 However, the privileged position of the Permanent Five (P5), to whose diktats Derrida objected, ${ }^{33}$ was the price paid for effective collective action. It has long been recognized that the constitution of the Council "actually extended the sovereignty of the Great Powers." ${ }^{34}$

The presence of these unequal sovereigns in the SC renders the designation of rogue states possible: in a system where sovereign equality was a reality, there would be no entity with the standing to make the designation of rogue statehood. As Gerry Simpson explains, "Great Powers often identify or define the norms that place certain states in a separate normative universe." ${ }^{35}$ Anghie has suggested that the "civilizing missions" that can then be taken against such states are a manifestation of "imperial expansion." ${ }^{36}$ In the UN collective security system, it is not enough that the P5 can guarantee the system with their capacity to marshal the troops and resources to undertake Chapter VII action; they must do this legitimately. Or, at least, they must not be seen to do so illegitimately. The threat to the entire community posed by a rogue state eases the process of legitimation.

\section{Unequal Sovereigns}

The concept of the rogue state is particularly associated with the US, "the world's sole superpower." ${ }^{37}$ The first use of the phrase is said to have been in The Washington Post in $1973^{38}$ and it became entrenched in American political discourse when it was adopted during the early years of the Clinton administration. ${ }^{39}$ In 2000, the Clinton Administration attempted to drop the term, and a Department of State spokesman explained that "[t]his is more a change in our description of things rather than a change in what we've been

\footnotetext{
${ }^{32}$ DERRIDA, supra note 2, at 98.

${ }^{33}$ Id. at 99.

${ }^{34}$ Jamer Brierly, The Covenant and the Charter, 23 BRITISH YEARBOOK OF INTERNATIONAL LAW (BYIL) 83, 91-2 (1946).

${ }^{35}$ SIMPSON, supra note 7 , at 6.

${ }^{36}$ Antony Anghie, On Critique and Other, in INTERNATIONAL LAW AND ITS OTHERS 394 (Anne Orford ed., 2006).

${ }^{37}$ Thomas M. Franck, The Power of Legitimacy and the Legitimacy of Power: International Law in an Age of Disequilibrium 100(1) AJIL 88, 97 (2006).
}

38 According to, inter alia, the Oxford English Dictionary Online, available at: http://www.oed.com/view/Entry/166894?redirectedFrom=rogue\%20state\#eid25187963 (last accessed: 24 April 2012).

${ }^{39}$ National Security Council of USA, National Security Strategy (February 1995). 
doing. ${ }^{\prime 40}$ Similarly, it could be that although the term rogue state has vanished from the official publications of the Obama administration, ${ }^{41}$ its spirit endures.

On its face, the Obama administration in the US presents a fundamental change from the Bush administration: it has committed itself to multilateralism and working through international institutions and it has, to an extent, distanced itself from the use of force. ${ }^{42}$ However, their policies regarding collective security share a key tenet: Sovereign inequality. In September 2009, President Obama announced "a new era of engagement" and "mutual respect." He said that the problems faced by all nations would require " $[\mathrm{t}] \mathrm{he}$ cooperative effort of the whole world." ${ }^{43}$ Such a position is by no means new: the observation that it is a "small world" is a cliché. Indeed, it is over ten years ago since former UK Prime Minister, Tony Blair, gave his famous "doctrine of international community" speech in which he observed that "[w]e are all internationalists now, whether we like it or not." ${ }^{\prime 4}$ Similar sentiments are to be found in the most recent high-profile UN document concerning collective security, A More Secure World, Our Shared Responsibility. ${ }^{45}$

This philosophy can be extended to tackling threats to international peace and security like international terrorism and nuclear proliferation. Indeed, throughout the last decade, the $\mathrm{SC}$ engaged in projects that required blanket participation rather than donations from a few able states. A good example of this is the Counter Terrorism Committee and its monitoring work. ${ }^{46}$ Other examples include the sanctions regimes leveled at North Korea and Iran. At a recent address to the Security Council, Secretary of State Hilary Clinton stressed the US' commitment to multilateral institutions and their importance in a "comprehensive approach" to countering such threats. ${ }^{47}$

Bearing this in mind, the participation and support of most, if not all states in security initiatives concerns not only the legitimacy of action, but also its effectiveness. Garnering

\footnotetext{
40 Richard Boucher, State Department Daily Press Briefing, Jun. 19, 2000, available at: http://19972001.state.gov/www/briefings/0006/000619db.html (last accessed: 24 April 2012).

${ }^{41}$ US NSS 2010, supra note 5 , at 2.

${ }^{42} / d$. at $12-13$.

${ }^{43}$ Barack Obama, Responsibility for our Common Future, address to the UN General Assembly Meeting, $64^{\text {th }}$ Session, Sept. 23, 2009.

${ }^{44}$ Tony Blair, Doctrine of the International Community, address to the Economic Club of Chicago, Apr. 24, 1999.

${ }^{45}$ High-Level Panel on Threats, Challenges and Change, a More Secure World: Our Shared Responsibility (2004).

${ }^{46}$ Established under UN Doc. S/Res/1373 (2001).

${ }^{47}$ UN Doc. S/PV.6390, $6390^{\text {th }}$ Meeting of the Security Council (2010).
} 
support and cooperation often involves the creation of reasons to do so: one of these is the rogue state. The concept of the rogue state provides two sorts of reasons: one positive and one negative.

The positive role played by the concept of the rogue state is that it indicates the magnitude of the threat facing the international community and the necessity for taking action. This is connected with the idea that rogue states are not only outside the community, but that their identity lies in their hostility to the community. ${ }^{48}$ Rogue states are presented as a threat to the entire "international community," and not just particular states within it. This impression is aided by the eagerness of states to identify themselves with the purportedly universal norms of liberal democracy. ${ }^{49}$

In this way, rogue states can be seen as a means of generating an external aspect for an otherwise "all-embracing" international community of states as a whole. ${ }^{50}$ It means that some states, prima facie members of the community by dint of their statehood, can be excluded on the grounds of their values or interests. This suggests an international community that is not simply another way of saying "all states," but a positive community of interests and values. The pursuit of this sort of community may seem like "imperialism in disguise" because "there is no agreement on the character of a desirable community."

In close connection, the negative role played by the concept of the rogue state relates to the Otherness of rogue states. As Derrida explained, "[t]he voyou is always the other always designated in the second or third person." ${ }^{25}$ The rogue state is exceptional: measures taken against such an aberration are not assumed to be applicable to the general body of states. For instance, measures taken against Iran, such as the demand that it cease enriching uranium, ${ }^{53}$ are not leveled against other countries that have developed nuclear fuel reactors such as Brazil - or even countries well known to have nuclear weapons programs - such as India. This exceptionality means that states can support intrusive

\footnotetext{
${ }^{48}$ DERRIDA, supra note 2, at 64.

${ }^{49}$ For example, the Millennium Declaration, adopted unanimously by the General Assembly on 8 September 2000, listed the values of Freedom, Equality, Solidarity, Tolerance, Respect for Nature and Shared Responsibility as fundamental values: see UN Doc. A/Res/55/2 (2000).

${ }^{50}$ Bruno Simma \& Andreas L. Paulus, The 'International Community': Facing the Challenge of Globalization 9(2) EJIL 266, 268 (1998).

${ }^{51}$ MartTI KoskenNiemi, From Apology to Utopia: The Structure of INTERNATIONAl Legal ARgumentation (2005).

${ }^{52}$ DERRIDA, supra note 2, at 64

${ }^{53}$ See for example, UN Doc. S/Res/1696 (2006).
} 
measures that prima facie compromise sovereignty, ${ }^{54}$ without fearing that this will set a precedent that could one day be applied to their own activities.

The view that some states, by virtue of their deviance, are excluded from the sovereign protections expected by most states is also present in the literature. Professor Christian Tomuschat has stated that "[a] system of government that has fallen so deeply into decay deserves no protection against interference by the international community." ${ }^{55}$ While for a normal state, it may be the case that "“sovereignty" plays a role analogous to that played by "liberty" in domestic liberal discourse," ${ }^{56}$ in the case of a rogue state, sovereignty is an obstacle to justice or security. ${ }^{57}$ This is because sovereignty insulates states whose normviolating behavior would be termed deviant were they human individuals. ${ }^{58}$

Bearing in mind the thick international community of values and interests, it is possible to see the concept of rogue state as promoting the unequal sovereignty of Great Powers on the other side of the coin. The US has been the most energetic state in identifying rogues. It is in a position to do so because of its self-identification with values of liberal democracy and the rule of law. The Obama administration, ${ }^{59}$ no less than the Bush administration, ${ }^{60}$ identifies the US with human rights and democratic values. In both cases, these values are presented as universal. ${ }^{61}$ This seems commensurate with an observation of the historian E.H. Carr. He wrote that "the doctrine of the harmony of interests .... is the natural assumption of a prosperous and privileged class, whose members have a dominant voice in the community and are therefore naturally prone to identify its interest with their own." ${ }^{\prime 2}$

Both positive and negative roles of the concept of rogue state - in persuading states that action needs to be taken and in quieting their fears that such action may have undesired

\footnotetext{
${ }^{54}$ UN Charter art. 2(7).

${ }^{55}$ Christian Tomuschat, Obligations Arising for States Without of Against Their Will, 241 RECUEIL DES COURS 194, 342 (1993).

${ }^{56}$ KOSKENNIEMI, supra note 52 , at 300.

${ }^{57}$ For the idea that actors that are excluded because of their deviance are not trusted with their freedom, see Bauman, supra note 6, at 207.

${ }^{58}$ Id. at 206.

${ }^{59}$ US NSS 2010, supra note 5, at 35.

${ }^{60}$ US NSS 2002, supra note 4 , at 3.

${ }^{61}$ See for example, US NSS 2010, supra note 5, at 5. For the George H. W. Bush position, see NATIONAL SECURITY Council of USA, National SeCURity Strategy (2006).

62 Edward H. CarR, The Twenty Years' Crisis 1919-1939: An Introduction to the Study Of INTERnational Relations (1981).
} 
consequences - are fed by a grammatical ambiguity in the term rogue state. Derrida pointed out that it is not clear whether the word rogue is to be read as an adjective or a noun. ${ }^{63}$ If the word is to be taken as a noun together with the word state, the designation rogue state appears to say that the state is substantially a rogue. If however, it is to be taken as an adjective, then it seems merely to describe some temporary attribute manifested in voyou behaviour. ${ }^{64}$ The ambiguity of the phrase enables its users to evoke the essential difference and dangerousness of rogue states, while simultaneously leaving open the possibility of the removal of that label as part of a package deal with which to bargain. ${ }^{65}$

\section{Intervention and Isolation}

The ambiguity of the rogue state - whether it is an essentially wicked entity or contingently defined by certain policies or actions - relates to two methods of tackling the threat it poses: Intervention and exclusion. ${ }^{66}$ The thinking behind exclusion is "the hope ....is that a spell in the wilderness will make the pariah state come to its senses and reenter international society as a reformed character." ${ }^{\prime 67}$ The thinking behind intervention is, taken to its logical extent as it was in Iraq, regime change. It is possible to associate the policy of intervention with the previous Bush administration in the US, and isolation with the present Obama administration. ${ }^{68}$

The ambiguity of the term rogue state makes it seem possible that rogue states are capable of being reformed, of shedding the stigmatic qualifying adjective. At the same time, it enables other states to glide over the conceptual difficulty of reforming a sovereign state because of the essential difference of rogue states from the rest. The tactics of exclusion share a conceptual basis of sovereign inequality with the tactics of intervention. In this way, we might suppose that Obama's emphasis on isolation is not diametrically opposed to his predecessor's penchant for regime change.

\footnotetext{
${ }^{63}$ DERRIDA, supra note 2, at 79-80.

${ }^{64}$ Id. at $79-80$.

${ }^{65}$ It is thought that the Clinton Administration's adoption of "states of concern" rather than rogue states was a response to their negotiating position with respect to the Democratic People's Republic of Korea.

${ }^{66}$ SIMPSON, supra note 7, at 285.

${ }^{67}$ Id. at 284 .

${ }^{68}$ Isolation, in the guise of containment was also used by the Clinton administration; See, for example, National Security Council of USA, National Security Strategy, December 2000; US NSS 1995, supra note 40, at 2.
} 
Intensifying this is the impression that the tactics of exclusion and intervention can be seen on a continuum. The structure of Chapter VII of the UN Charter suggests that exclusion of a state from the "international community" can be seen as a precursor to its intervention. This is mirrored by the progression through article 41 to article 42 in Chapter VII. Although the sanctions envisaged in article 41 can be seen as interventions in the domestic sphere of a sovereign state in a broad sense, they are "measures not involving the use of armed force." ${ }^{\prime \prime 9}$ Article 42 measures may be taken "[s]hould the Security Council consider that measures provided for in Article 41 would be inadequate or have proved to be inadequate...." ${ }^{70}$ Article 42 measures are seen as "exceptional;" to be used only in case measures not involving the use of military force are ineffective.

The Obama administration has been using the tactic of isolation in the cases of Iran and North Korea: progressively tougher sanctions are leveled at these states as their failure to comply with the SC obligations continues. For instance, the administration's policy towards Iran centers around the integration or exclusion of that state in international society: Obama has said that "[w]e want Iran to take its rightful place in the community of nations, politically and economically .... [O]r the government can choose increased isolation [and] international pressure...." ${ }^{72}$ In this sense there has been little change from the Bush administration's use of sanctions to enforce compliance. The "suspension-for-suspension" understanding - that sanctions will be suspended as soon as Iran suspends its proscribed activities - persists. ${ }^{73}$ Furthermore, both administrations refused to rule out ultimately resorting to force. ${ }^{74}$

The difference lies in the present administration's willingness to "engage" with Iran. The so-called E3+3 (China, France, Germany, Russia, the UK and the US) have adopted a "dualtract" approach that consists of sanctions and dialogue. Obama's prominent policy of "engagement" is one that promises to bring recalcitrant states, isolated from international

\footnotetext{
${ }^{69}$ UN Charter art. 41.

${ }^{70}$ UN Charter art. 42.

${ }^{71}$ Jochin Frowein \& Nico Krisch, Article 42, in THE CHARTER OF THE United NATIONS: A COMmentaRY 753 (Bruno Simma ed., 2002).

72 Barack Obama, Hradcany Square, Prague,, Apr.5 2009, available at: http://www.whitehouse.gov/the press office/Remarks-By-President-Barack-Obama-In-Prague-As-Delivered/ (last accessed: 24 April 2012).

${ }^{73}$ The UK's permanent representative at the Security Council, Sir Mark Lyall Grant, expressed this rationale in the Security Council meeting at which SCR 1929 (2010) was passed; see UN Doc. S/PV.6335 (2010).

${ }^{74}$ US Chief of Staff Admiral Mike Mullen has not only said that military actions remain on the table, but also that the military has already made "a plan"; see transcript from "Meet the Press," MSNBC, Aug. 1, 2010, available at: http://www.msnbc.msn.com/id/38487969/ (last accessed: 24 April 2012).
} 
society, back into the fold. ${ }^{75}$ The idea that it may be worth engaging with rogue states also points to the view of them as quasi-criminal entities defined according to their violation of norms of order. As Bauman has explained, "[t]he very ideas of order and norm are born of that sense of (rectifiable) imperfection." ${ }^{76}$

According to the current US National Security Strategy, states are isolated when they fail to meet their international responsibilities:

Those nations that refuse to meet their responsibilities will forsake the opportunities that come with international cooperation. Credible and effective alternatives to military action-from sanctions to isolation-must be strong enough to change behavior, just as we must reinforce our alliances and our military capabilities. And if nations challenge or undermine an international order that is based upon rights and responsibilities, they must find themselves isolated ${ }^{77}$

However, the consequences that flow from failure to meet international responsibilities depend on the status of the state concerned. ${ }^{78}$ It seems, then, that only certain sorts of states are isolated. The states that are isolated are those whose failure to comply with international responsibilities appears to render them a threat to international peace and security. It could be said that the fact of non-compliance as a measurable and visible event manifests what is otherwise an uncertain and unformed threat to peace and security. ${ }^{79}$ The very isolation of states in this way renders them "rogue" to the extent that a rogue state is one placed temporarily or constitutionally outside international society. ${ }^{80}$

This understanding of the concept of rogue statehood leads us back to Derrida's understanding of the term as relating to the rejection of international law. ${ }^{81}$ In the context

\footnotetext{
${ }^{75}$ US NSS 2010, supra note 5, at 11-12.

${ }^{76}$ Bauman, supra note 6, at 206.

${ }^{77}$ US NSS 2010, supra note 5, at 12.

${ }^{78} \mathrm{See}$, for example, ANTONIO CASSESE, INTERNATIONAL LAW IN A Divided WORLD (1986).

79 Isobel Roele, Ascertaining Inchoate Threats to International Peace and Security, in INTERNATIONAL LAW IN A MULTIPOLAR WORLD (Mathew Happold ed., 2011).

${ }^{80}$ Interestingly the Oxford English Dictionary online edition suggests that the word 'rogue' originally meant vagrant or vagabond. These individuals wandered across the country rather than being included in any particular society; see generally, THE OXFORD ENGLISH DICTIONARY, available at: http://www.oed.com/ (last accessed: 24 April 2012).

${ }^{81}$ DERRIDA, supra note 2.
} 
of domestic criminal law, Zygmunt Bauman has written about how the pursuit of order in societies characterized by uncertainty and insecurity invites a paradigm of exclusion. ${ }^{82}$ Those who do not fit into the dominant order are abnormal because they do not comply with society's norms. At the extreme reaches of abnormality is deviance. ${ }^{83}$ Rogue states are deviant in this regard.

The rogue state is identified not by a particular manifestation of violence, but by its attitude to international society as demonstrated through its compliance with international legal obligations. In Iran's case, such compliance was presented, both by the International Atomic Energy Agency ${ }^{84}$ and by the $\mathrm{SC}^{85}$ as a matter of confidence building. Lack of confidence in Iran flowed from its failure to comply with "community" obligations, which in turn could only be rectified by compliance. This seems borne out by the stated purpose of the US and its allies to use the tactics of isolation to encourage Iran to come back into the fold. ${ }^{86}$ The US policy is echoed in Bauman's understanding of the operation of norms: norms translate "the concept of order into the language of human choices." ${ }^{87}$ In this respect, a state like Iran or North Korea can be seen as excluded by dint of its own choices, ${ }^{88}$ and consequently capable of choosing to be reintegrated.

It is worth emphasizing that the linkage of the concepts of threat and responsibility is not limited to the US and its allies. The UN has also adopted the rhetoric of responsibility. ${ }^{89}$ This echoing of strategy can be used as a stepping-stone to the controversial issue of state crime: we can understand the tactic of isolation by analogy to the human equivalent of imprisonment. In withdrawing international commerce and diplomatic relations, states implementing the sanctions called for the by SC are essentially cutting states like Iran and North Korea off from society in a similar way that inmates in prisons are cut off from society.

\footnotetext{
${ }^{82}$ Bauman, supra note 6, at 207.

${ }^{83} / d$. at 206.

${ }^{84}$ International Atomic Energy Agency Doc. GOV/2006/14 (2006).

${ }^{85}$ UN Doc. S/Res.1696 (2006).

${ }^{86}$ Bauman, supra note 6, at 206.

${ }^{87}$ Id. at 206.

${ }^{88} / d$. at 207.

${ }^{89}$ Report of the High-Level Panel on Threats, Challenges and Change, supra note 46, at 17.
} 


\section{Criminal States?}

Derrida said that the term voyou always "begins to justify some sanction." ${ }^{\prime 90}$ It could be said that the designation of a state as a rogue state acts in place of the criminal justice label guilty. This goes further than Derrida who said that "[w]hen speaking of a voyou, one is calling to order; one has begun to denounce a suspect." ${ }^{91}$ The suggestion is not an easy one. However, the controversy of the idea of state criminality suggests that there is an important legitimizing role to be played by the rogue state. ${ }^{92}$ This section sets out the preliminary ground for linking the concepts of rogue statehood and criminality.

Perhaps the only aspect of criminal responsibility of states that is not controversial is that the notion is controversial. There are practical objections to state criminality: For instance, it may encourage states to become self-appointed policemen of the international community. ${ }^{93}$ There are also conceptual objections: States are abstract entities with "no soul to damn and no body to kick." ${ }^{94}$ In this vein, the Nuremberg International Military Tribunal (IMT) stated that "crimes against international law are committed by men, not abstract entities." ${ }^{95}$

However, there has been sufficient discussion of the issue to suggest that the concept of state crime is worth considering. For instance, the International Court of Justice (ICJ) has thrown doubt on whether the IMT dictum rules out the possibility of state crime altogether. In the Bosnia Genocide case, it suggested that the statement should be taken in the context of the IMT's refutation of the argument that only states could be responsible under international law. ${ }^{96}$ Ultimately, however, the ICJ shied away from recognizing the obligations in the Genocide Convention as state crimes. ${ }^{97}$ The catalyst for the most concerted discussion of state crime was article 19 of the International Law Commission's (ILC) draft on state responsibility. While, ultimately, all references to state crime were

${ }^{90}$ DERRIDA, supra note 2 , at 79.

${ }^{91}$ Id. at 64.

${ }^{92}$ DERRIDA, supra note 2 , at 64.

93 UN Doc. A/53/10 (1998); International Law Commission, Report of the International Law Commission on the work of its fiftieth session (1998).

${ }^{94}$ Phrase attributed to eighteenth century Lord Chancellor of Great Britain, First Baron Thurlow; See, for example, John Coffee, 'No Soul to Damn and No Body to Kick': An Unscandalized Inquiry into the Problem of Corporate Punishment 79(3) MICH. L. REV. 386 (1980-1).

${ }^{95}$ Nuremberg International Military Tribunal, Judgment and Sentences, 41(1) AJIL 172, 221 (1947).

${ }^{96}$ Application of the Convention on the Prevention and Punishment of the Crime of Genocide (BIH v. SRB), 2007 I.C.J. 43, at 172 (Feb. 26, 2007).

${ }^{97}$ Id. at 170. 
lifted from the Articles on State Responsibility that were adopted by the General Assembly, the issue was debatable enough to merit serious consideration. ${ }^{98}$ In 1976, the ILC agreed to a definition of international crime. Draft article 19(2) read

An internationally wrongful act which results from the breach by a State of an international obligation so essential for the protection of fundamental interests of the international community that its breach is recognized as a crime by that community as a whole, constitutes an international crime. ${ }^{99}$

In the following paragraph, the ILC even gave some explanatory examples of international crimes. Draft article 19(3)(a) read

3. Subject to paragraph 2, and on the basis of the rules of international law in force, an international crime may result, inter alia, from:

(a) a serious breach of an international obligation of essential importance for the maintenance of international peace and security, such as that prohibiting aggression. ${ }^{100}$

The notion of state crime is entwined with the idea of international community, which is also related to the use of the rogue state as a means of defining the community. ${ }^{101}$ Crimes are committed against a community as a whole, even where only one actor has suffered direct harm. ${ }^{102}$ In national legal systems, this is reflected by the idea that the prosecution represents, for instance, Regina in the UK or the People in the US. ${ }^{103}$ To the extent that the SC purports to act on behalf of all UN member states ${ }^{104}$ and to the extent that these

\footnotetext{
${ }^{98}$ UN Doc. A/53/10 (1998); International Law Commission, supra note 95; Official Records of the General Assembly, Fifty-third session, Supplement No.10, at 64-77.

99 UN Doc. A/31/10 (1976); INTERNATIONAL LAW COMMISSION, REPORT OF THE INTERNATIONAL LAW COMMISSION ON THE WORK OF ITS TWENTY-EIGHTH SESSION (1976); Official Records of the General Assembly, Thirty-first session, Supplement No. 10, at 95-96.

${ }^{100}$ Id. at 95-96.

${ }^{101}$ DERRIDA, supra note 2.

${ }^{102}$ The ways in which crime can be understood as a public matter are interestingly considered by G. Lamond, What is a Crime?, 27(4) OJLS 609, 614 (2007).

${ }^{103}$ Sandra E. Marshall and Antony Duff, Criminalization and Sharing Wrongs, 11(1) CAN. J. L \& JURIS. 7, 15 (1998).

${ }^{104}$ UN Charter art. 24(1).
} 
member states constitute an international community, the SC can be seen to play a similar role.

Crimes are breaches of certain obligations owed to the community as a whole. ${ }^{105}$ The notion of obligations erga omnes was set out by the ICJ in the Barcelona Traction case: "By their very nature [they] are the concern of all States. In light of the importance of the rights involved, all States can be held to have a legal interest in their protection." ${ }^{106}$ The concept of obligations erga omnes marked a fundamental departure from the idea of international law as a collection of bilateral agreements and was viewed by some as contributing to the evolution of international law as global community law. ${ }^{107}$ In this respect, the notion of state crime can be seen as an extension of the idea of obligations erga omnes. ${ }^{108}$ To the extent that state crime involves the idea of a state being responsible to the international community rather than to the specific injured state, it can be seen as a manifestation of unequal sovereignty. This is sharpened when the specific area of responsibility relates to peace and security, the subject matter of community-wide importance. The fact that decisions about peace and security are the province of the SC and that they are taken to be made on behalf of UN member states also supports this reading. ${ }^{109}$

This impression is intensified if one subscribes to the view that the enforcement of criminal law implies a vertical system of authority. In other words, that the identification and application of such laws requires a higher authority to represent the "international community." The frequency with which the UN and its Charter are identified with the "international community" 110 suggest that the SC is a prime candidate to act as such an authority. ${ }^{111}$ This is also suggested by claims that SC resolutions express the "will of the international community" and that their enforcement is the enforcement of that will. ${ }^{112}$

\footnotetext{
${ }^{105}$ Many commentators writing on state crime are careful to note that not all breaches of obligations erga omnes could be considered criminal; see, for example, Geoff Gilbert, The Criminal Responsibility of States, 39(2) ICLQ 345, 355 (1990); James Crawford, First Report, UN Doc. A/53/10 (1998) 69, at 278-279.

${ }^{106}$ Barcelona Traction, Light and Power Company, Limited (NV v. ES) (New Application: 1962), Second Phase, ICJ Reports, (Feb. 5, 1970), at para. 33.

107 UN Doc. A/53/10 (1998); International Law Commission, supra note 95; Official Records of the General Assembly, Fifty-third session, Supplement No.10, 67 at 265.

${ }^{108}$ Bruno Simma, From Bilateralism to Community Interest, 250 RECUEIL DES COURS 217, 306 (1994 VI).

${ }^{109}$ Happold, supra note 31.

${ }^{110}$ Bardo Fassbender, The United nations Charter as the Constitution of the INTERnational Community (2009); Nigel White, The Legality of Bombing in the Name of Humanity 5(1) JCSL 27, 28-29 (2000); Christian Tomuschat, Obligations Arising for States Without of Against Their Will, 241 RECUEIL DES COURS 194, 334 (1993 IV).

${ }^{111}$ And within the SC, the P5; HIGH-LeVel PANel On Threats, Challenges AND Change, supra note 46.

${ }^{112}$ See, for example, Tony Blair in Hansard HC vol. 390 col. 5, Sept. 24, 2002.
} 
Indeed, in his discussion of state crime in his Hague Academy Lectures, Judge Bruno Simma suggested "the principal sedes materiae of such organized collective enforcement [the reaction to international crimes] will be Chapter VII of the United Nations Charter."113

The overlap of state crime and threats to international peace and security is apparent from the presence of aggression in article 39. The IMT at Nuremberg labeled it the "supreme international crime."114 It has been said "aggression is necessarily a crime of the state."115 However, leaving aside the question of who is prosecuted for its commission, the dual identity of aggression as both a crime and a threat to international peace and security was recognized in the 2011 Review Conference on the Rome Statute that took place in Kampala. The newly negotiated definition of aggression expressly connects the two uses of the term by apparently suggesting that the ICC prosecutor should consider whether the SC has made a finding of aggression before he proceeds with such a prosecution. ${ }^{116}$

In practice the SC has not made findings of aggression under article $39 .{ }^{117}$ Its practice has been to simply find a threat to international peace and security in order for Chapter VII measures to be taken. Neither Iran nor North Korea, for instance, has been labeled an aggressor in any SC resolutions. Nevertheless, it seems that when a state is labeled a rogue state on the grounds that it has demonstrated its unwillingness to uphold its international responsibilities by complying with its obligations, ${ }^{118}$ there is a clear parallel with criminal law. Sanctions are a sort of punishment - albeit one with a rehabilitative aim rather than a retributive one - imposed for breach of obligations owed to the international community as a whole.

Sanctions regimes isolate the target state. This isolation is both material, for instance, insofar as other states may not trade with them, and notional, for instance, insofar as there is a stigma attached to being on the receiving end of SC sanctions. The process of isolating a state by subjecting it to sanctions places it beyond the community, but not beyond the law. Although a rogue state's sovereign equality is undermined, the fact that it is subject to law is underscored. In this sense, isolation is not unlike imprisonment: both are means of effectively stymieing freedom and of "estranging" an unstable element from

\footnotetext{
${ }^{113}$ Simma, supra note 110 , at 309.

${ }^{114}$ Nuremberg International Military Tribunal, Judgment and Sentences, 41(1) AJIL 172, 186 (1947).

${ }^{115}$ Robert Cryer et. al., Introduction to International Criminal LAW ANd Procedure (2010).

${ }^{116}$ Resolution RC/Res.6, The Crime of Aggression, Adopted at the 13th plenary meeting, on 11 June 2010, by consensus, article 15.

${ }^{117}$ But $c f$. the "acts of aggression committed by the racist regime of South Africa" against Angola, which were condemned in UN Doc. S/Res/602 (1987).

${ }^{118}$ Bauman, supra note 6, at 207.
} 
society. ${ }^{119}$ Similarly, Simpson has referred to "a quasi-penal regime of responsibility and constraint" in connection with the treatment of rogue states. ${ }^{120}$

This can be tied into the understanding of a rogue state as a state that is opposed to the existing order and that seeks to disrupt it. As indicated above, ${ }^{121}$ this opposition is demonstrated by a state's failure to comply with expressions of the "will of the international community" in the form of legal obligations imposed by the Security Council. In Obama's National Security Strategy, this translates into an overall emphasis on "responsibility." In a world of connected security threats that can only be tackled by the concerted closing of illicit supply routes, monitoring of borders and general implementation of best practice models domestically, any state that fails in these responsibilities contributes to disparate and undefined threats of international terrorism and WMD proliferation.

\section{Conclusion}

This paper has argued that the concept of the rogue state, though apparently absent from US security documents, is implicit in the policies of the Obama administration. This is reflected by the resurfacing of the phrase "rogue regime" in speeches by the Secretaries of State $^{122}$ and Defense ${ }^{123}$ and even by the President himself. ${ }^{124}$ The reason for this is that the concept of the rogue state, as a breed of "unequal sovereign" in the sphere of international peace and security, is too useful to be jettisoned completely. It represents an 'Other' that justifies the criminalization of certain states. Far from having disruptive effects, the concept of the rogue state can promote a sense of international community, can smooth the way for collective security action and can avoid the appearance of conflict between fundamental principles.

\footnotetext{
${ }^{119}$ Bauman, supra note 6, at 208.

${ }^{120}$ SIMPSON, supra note 7 , at 284 .

${ }^{121}$ DERRIDA, supra note 2.

${ }^{122}$ Press release, Briefing by Secretary Clinton, Secretary Gates, Admiral Mullen on the announcement of the new START treaty (Office of the Press Secretary), THE WHITE HOUSE, Mar. 26, 2010, available at: http://www.whitehouse.gov/the-press-office/briefing-secretary-clinton-secretary-gates-admiral-mullenannouncement-new-start-tr (last accessed: 24 April 2012).

${ }^{123}$ Press release, Robert Gates, Secretary of Defence Interview With Judy Woodruff, THE NEWS HOUR WITH JIM LEHRER, Apr. 7, 2009, available at: http://www.defense.gov/transcripts/transcript.aspx?transcriptid=4397 (last accessed: 24 April 2012).

124 Press release, Remarks by the President to CIA Employees (White House, Office of the Press Secretary), CIA HEADQUARTERS, Apr. 20, 2009, available at: http://www.whitehouse.gov/the-press-office/remarks-president-ciaemployees-cia-headquarters (last accessed: 24 April 2012).
} 
If the absence of the rogue state from the current US administration's security documents was intended to signal a move away from the machismo of the Bush Doctrine, it has not signaled a move away from policy based on the inequality of sovereign states. Obama's foreign policy is based on sovereign responsibility and failures in such responsibility are to be tackled with isolation and engagement. These dual measures may take the form of sanctions and dialogue, as in the case of Iran, and are related to the position of the target state vis-à-vis the "international community."

The necessity of gaining the support and cooperation of other states for the implementation of wide-ranging measures to prevent and suppress genres of threat such as international terrorism or the proliferation of WMD rests on the accepted inequality of the rogue state. This acceptance hinges on the perception of the rogue state as dangerous or deviant. Such a perception can segue into a view of rogue states as criminal states insofar as it flows from their failure to live up to the responsibilities they owe to the "international community." The isolation of such states seems to correspond to the exclusion practiced in domestic criminal regimes. This ties in with the idea of the rogue state as a state defined by its non-compliance with norms of order: on the one hand, suggesting the possibility of redemption through conformity, and on the other the threat of disorder. 